\title{
INCREASING OPERATIONAL CAPABILITIES OF NATO IN THE FACE OF MODERN CHALLENGES AND THREATS
}

\author{
Col. Bogdan GRENDA, Prof. PhD \\ b.grenda@akademia.mil.pl \\ Faculty of National Security \\ War Studies University, Warsaw, Poland
}

\begin{abstract}
This paper explores the issue of improving NATO's operational capabilities. The initial sections overview changes that have already been introduced and are expected in the international security environment in the forthcomingyears. This perspective is subsequently adopted to identify the present developments in the strategic concepts of NATO with the view to formulation of appropriate operational capabilities of the North Atlantic Treaty.
\end{abstract}

Keywords: threat, operational capabilities, strategic security environment

\section{Introduction}

The end of the bipolar world has affected the European security environment, which as a result has become more turbulent and susceptible to destabilisation. In the Cold War era, in spite of the objective threats, the security environment appeared less ambiguous and more predictable. Although it was indeed dominated by the incessant clashes of two antagonistic blocs, communism and democracy, it did seem internally stable. According to Z. Brzezinski, the true source of the bipolarity in the world was the struggle between the USA and USSR over 
the future of Europe, concerning the extent of the future political influence of Russia and America. The Russians were hopeful that the Americans would leave Europe at the end of World War II, which would open the gate for Russian domination on the continent. This was, however, not the case. The confrontation line led to the establishment of the world's most powerful alliances, NATO and the Warsaw Pact.

NATO - the North Atlantic Treaty Organisation - was established in Washington on 4 April 1949 in accordance with the Vandenberg Resolution, passed by the US Senate in June 1948. The resolution justified and urged the governments to organise military blocs as a countermeasure to the Russian threat. The major role of the North Atlantic Treaty is to apply the available political and military means to guarantee freedom and true security to all of its member states, according to the rules formulated in the Charter of the United Nations.

The North Atlantic Treaty was established in response to the challenges posed by the Cold War, and is under constant transformation in order to meet new challenges to international security. Organised around the principles of collective defence and the collective security of its member states, NATO successfully maintained the strategic balance in Europe throughout the Cold War and guarded the freedom and independence of the Allies. According to the provisions of the North Atlantic Treaty, the Alliance continues to fulfil the fundamental goals, which ensure stability in the Euro-Atlantic zone, and furthermore undertakes new initiatives that result from the new strategic conditions and emerging threats to security. NATO strives to promote stability, which flows from the shared democratic values and respect for human rights and the rule of law in Europe. Since the early 90 s and the formulation of new fundamental objectives in the name of security, the organisation, structure and politics of NATO have been evolving, which included acquiring new capabilities, missions, members, partnerships and new modus operandi, all in response to the new future, which is identified as increasingly complicated and uncertain, whose opportunities and challenges are strictly related to its driving force, i.e. the high tempo of changes in numerous fields: social, economic, scientific, technological and environmental protection.

It is for the abovementioned reasons that the present article is primarily devoted to identifying the operational capabilities of the North Atlantic Treaty in response to the anticipated future challenges and threats. 


\section{Necessary operational capabilities of NATO}

Prior to exploratory attempts in the subject of operational capabilities, the term itself requires defining. For the sake of this analysis, operational capability is regarded as the potential and the capability of an actor to undertake certain actions and complete desired objectives, based on their character and properties. The proposed definition is a derivative of the term put forward in the Aims of Armed Forces of NATO and is furthermore fully compliant with the requirements of this work (Order nr 56 MON 2013, p. 1).

According to the predicted course of evolution of the strategic security environment, the future changes are expected to exert a negative impact on security in the transatlantic zone. It is anticipated that the threat from barely identifiable non-state actors will be mounting. Destabilisation of state structures in areas of strategic importance will require NATO intervention in the form of expeditionary actions, which may involve: securing access to mineral resources, provision of security to transportation routes, combating weapons of mass destruction and conflict prevention. With the purpose of securing its own interests, and in pursuit of global security, the Alliance is obliged to constantly increase its capabilities in order to secure the necessary resources that enable engagement in different sectors of the world, in various military and non-military operations.

The changes observed in the strategic security environment suggest that the primary challenge will be the varied character of concurrently emerging threats and, simultaneously, the rise of new unprecedented threats and phenomena previously unrecorded in history. These threats are likely to occur in various geographic environments and combine different military and non-military operations. A large number of contemporary theoreticians argue that the conflict of the future will probably be civilised, and the Clausewitzian paradigm of warfare, understood as: “... legitimate use of violence as a means of imposing one's will on the adversary," (Banasik 2015, p. 110) will lose the former significance as politics is conducted by other means (Balcerowicz nd.).

In the past, success was equated with the achievement of strategic objectives, i.e. inflicting loss on enemy troops and forcing the adversary to cease its activities. However, in the future security environment, the role of military forces will 
consist in establishing the background for the implementation of other means of diplomatic, economic or political nature. Nevertheless, recent history appears to call into question these predictions, as, in 1995, an apparently civilised Europe was the location of a theatre of ethnic cleansing in Bosnia. Following an embarrassing and disastrous failure of diplomacy, these were hostilities that succeeded in putting an end to the genocide. A similar scenario took place in Kosovo, where had it not been for the decisive air strikes of the US army, the Serbian army would probably not have withdrawn from the republic. The recent campaign of the Coalition forces against the Islamic State is yet another example that provides an argument against the case. The evolution of the strategic security environment, the diagnosed threats and new challenges appear to indicate that the future strategic security environment is likely to remain unpredictable and non-uniform to a considerable extent.

The source of threat might originate in developed as well as in radical states, not to mention non-state actors with nuclear, chemical or biological weapons at their disposal. In the face of growing competition for natural resources, sea assets, and the potential of outer space, not to mention the sweeping wave of regional conflicts, NATO may be obliged to intervene in areas outside the traditional sphere of engagement. NATO forces will therefore have to exhibit the potential for preparing and conducting decentralised activities and adaptability to a range of complex fast-changing situations. The military force of the Alliance will be required to act in both regular and irregular forms of military activities.

Powerful new actors emerging on the global scene, equipped with advanced military technology, which they would not hesitate to employ in any environment, including outer space and cyberspace, are bound to become a serious threat and challenge to NATO. The war zone of the future will be characterised by high complexity, and the warfare might embrace different dimensions: maritime, land, space, aerial and cyberspace. NATO forces must be equally well prepared for state and non-state adversaries, which has already taken place. The adversary incapable of a direct clash of arms will implement asymmetrical, hybrid actions, the type of warfare that NATO forces must be prepared for, and thetype of warfare that might take the form of long-term conflicts, which demand solutions engaging various actors, e.g. international and non-governmental organisations and institutions. 
Presumably, the conflict of the future will involve depreciation of international humanitarian law. The warfare in Rwanda, former Yugoslavia, and against the Islamic State organisation have all undermined the idealistic image of war - the confrontation of regular armed forces (Baylis Wirtz Gray Cohen 2009, p. 125). Land forces are expected to remain the dominant formation of NATO military, partly due to their unique capability to seize and maintain control over objects, unlike other formations, which are capable of only destroying targets. Furthermore, it is exclusively the land forces that ensure territorial integrity by exercising control over a given territory, which is the attribute of a sovereign state.

In order to face future threats, NATO forces might have to engage in areas outside the Euro-Atlantic region and develop full readiness to oppose new forms and types of military operations. Regardless of the character of performed operations, NATO military forces will have to acquire new operational capabilities, and update and transform the currently possessed ones to ensure their effective reaction to threats arising in the changing security environment. These capabilities are and will prove to be indispensable in conducting a wide range of activities and operations, and achieving the desired effects with the implementation of suitable weapon systems (Banasik 2015, pp.136-137). On the other hand, the functional capabilities (United States Department of Defense 2011, p. III) i.e. intelligence, fire, movement and manoeuvre, protection, and sustainment will provide support for the former tasks.

According to the Strategic Concept formulated in 2010, NATO members are expected to maintain the capability to deter and defend against potential new threats and manage crisis. With a view to accomplishing these objectives, NATO should develop and maintain conventional expeditionary forces able to sustain Major Joint Operations ${ }^{1}$. The Concept has put forward a number of resolutions critical to the security in the transatlantic area, which ensure the effectiveness of the Alliance in the modern world, and against potential new challenges. These settlements have been set out in Article 5 of the Washington Treaty ${ }^{2}$, the founding document of the Treaty. However, should the USA decide that NATO

1 Major Joint Operation, MJO, is defined in Ministry Guidelines 2003. Major Joint Operation can last for 2 years.

2 Article 5 is the foundation of the North Atlantic Treaty, the defence of our Motherland is the foundation of the security system of the Republic of Poland. Author's note. 
is incapable of facing the threats and challenges, the Alliance may be considered as an organisation that does not guarantee security in the transatlantic area, and, therefore, be deemed dispensable. The disproportion between the military potential of the USA and European members is large and growing. The technological impairment of European member states became seriously exposed during the military crisis in former Yugoslavia, where having considered the aforementioned condition, the USA decided to abstain from the military involvement of European allies as incompatible with American equipment and procedures. Similarly, the 2011 civil war in Libya revealed the operational incapacity of European states.

In recent years, the threat of confrontation over the North Pole has been gradually intensifying. One of the factors that had led to the increasing competition was climate change, which enabled extending the range of test boring in search for undiscovered energy sources and, furthermore, allowed companies to extract oil and gas from underneath the ice cap. American and European oil companies have been setting out to begin exploiting the extensive resources of the polar circle for years. The United States Geological Survey (USGS), one of the units of the United States Department of the Interior, has estimated that approximately $13 \%$ of the world's oil reserves and a third of the world's natural gas resources are located in the area. It is all the more important as climate change has led to more rapid disintegration of the ice sheet, which further accelerates the race for the multibillion dollar prize. As early as in 2012, Russia attempted to take over $1.2 \mathrm{~m} \mathrm{~km}^{2}$ of the ocean bed as a part of their territory, which roughly corresponds to the surface area of France and Spain. Russian interests referenced the United Nations Convention on the Law of the Sea, which permits extending state borders. The legal procedure has already been started. In the spring of 2015, Russia staged the first manoeuvres of their armed forces and Arctic Brigade, which included 50 vessels, 110 aircraft and 38 thousand troops over an area stretching from Novaya Zemlya and Franz Josef Land to the Kamchatka Peninsula and Sakhalin (Reiss 2018). The tensions surrounding the Arctic are expected to intensify, and it seems to be a matter of time before the situation gets out of control. The disputed area is an object of interest clash for four member states of the North Atlantic Treaty (the USA, Canada, Denmark and Norway), Russia, whose claims to Arctic territories are the most extensive, and China. Climate change has already increased the commercial viability of the formerly inhospitable Northern Sea and allowed the Northern Sea Route that connects Norway to the Pacific to be defined. 
A potential conflict in the Arctic region would require sustaining properly prepared land, air and maritime forces. While NATO Air Forces are perfectly capable of performing activities in the region, the land and maritime forces are ill-prepared for operating in Arctic scenarios, which would demand developing a fleet of ice-breakers ${ }^{3}$ (Dziennik 2018). Russia and Canada aim to obtain a legal permit to control vessels entering the future sea route, which has already been protested against by several states. To acquire the ability to operate in outer space should also be given high priority.

Russian Air and Space Forces (Russian Aerospace Forces) were established in 2015. The decision was dictated by the need to merge under one command all the forces and resources responsible for the provision of security to Russia against attacks from air and the outer space. As a result, the gravity of future activities has been shifted to air space and outer space (Dura 2015).

It appears, then, that the militarisation of outer space has entered the "production stage": new space units are formed, new weapon systems are put to the test. As a result, outer space around our planet is being transformed into a potential theatre of war, and other non-military activities. Developed countries have already become heavily dependent on outer space, be it in terms of satellites supporting military and civil communication, or meteorological or navigation systems. Even today, potential neutralisation of these systems would effectively lead to a communication paralysis, including the activities of all the armed forces. Although certain attempts have been made to regulate the code of conduct in outer space, a number of countries have not accepted the regulations. Militarisation of outer space has become a fact. It is estimated that a number of states have already placed their electronic warfare satellites, signal obstruction and other military systems in outer space. In order to acquire the operational capability in outer space to counteract threats emerging from its militarisation, the Alliance must be equipped with suitable tools and solutions.

Not only do crises and conflicts outside the NATO borders pose a direct threat to the member states, they also constitute a challenge to their security. It is for these very reasons that NATO should engage whenever and wherever it is possible

3 Russia owns 25 ice breakers, and is building new vessels, including armed. 
and necessary (Wrzosek 2013, p. 113). According to the current NATO Strategic Concept, prevention of threat begins outside the home, not where it is already developing but where it begins.

From the perspective of the armed forces, this requires improvements in the development of reconnaissance and reconnaissance strike systems. Furthermore, the Alliance should retain the nuclear capabilities within its deterrence measures as a token of credibility, particularly as long a nuclear threat exists on the part certain states $^{4}$ and non-state actors striving to acquire nuclear capabilities. Matthew Koenig, an American expert, highlights that at present, NATO is unprepared for a scenario in which Russia would use tactical nuclear weaponry against one of its member states. Koenig's opinion is shared by many experts in the field; however, there is no common consensus. In response to the emerging threats and challenges, the North Atlantic Treaty has implemented a range of initiatives with a view to improving its defence capabilities, including the following:

- Defence Capabilities Initiative - DCI;

- establishment of Weapons of Mass Destruction Centre ${ }^{5}$;

- development of the European Security and Defence Identity within NATO.

In a brief overview and critical analysis of the Defence Capabilities Initiative, it ought to be mentioned that DCI was a priority programme implemented in 1999. The initiative responded to the rising need for improving NATO's military capabilities in the face of changing conditions in the strategic security environment. The primary objective of the programme was to equip the Alliance with the means to conduct a wide spectrum of current and future activities, connected with both collective defence and crisis response on a global scale, and moreover to improve the interoperability between the armed forces of member states and the military capabilities regarding inter alia (Elinor 2010, p. 191):

- high mobility and rapid deployment of forces in distant operational areas;

- mobility and vitality of forces and limiting own casualties;

4 Russian military strategy states that Russia can obtain tactical nuclear weapons at an early stage. Virtually all big manoeuvres in the past 15 years involved nuclear attack on an adversary (Admin 2015)

5 Weapons of Mass Destruction Centre was established in 2000 and is a platform for dissemination among member states of the Alliance of information concerning the WMD threat and enables joint efforts in searching for correct crisis response solutions. 
- effectiveness of activities;

- protection of NATO forces at a great distance from permanent disposition;

- interoperable, fully mobile command and communication systems;

- IT (C2I).

In addition, the initiative was aimed at ensuring that the member states develop and adapt their military potentials to the extent required by future multinational operations of the Alliance, in particular in the context of crisis response. The foundation of expeditionary armed forces provided the means and capabilities to: swift performing operational activities, domination in all the dimensions of performed activities, i.e. land, air, sea, space and cyberspace.

The terrorist attacks in the USA on 11 September 2001 triggered a review of the Treaty procedures, which was concluded during the Prague Summit, where a series of initiatives and programmes were formulated and approved ${ }^{6}$ (GórkaWinter 2002). New initiatives were undertaken with the objective of: improving the military potential of member states in defence against terrorism, improving the interoperability and ensuring rapid deployment and sustaining of forces in the field. The NATO Response Force, also brought to life in Prague, provided the foundation for the expeditionary potential of the Alliance. The capabilities were increasingly important to handle a range of operations, from engaging in conventional full-scale warfare (as per the collective defence settlements formulated in Article 5), to supporting humanitarian actions in distant operational areas. The preparation of the Alliance for performing a broader range of activities required transforming the military and NATO command structures along with the political command structure. The main priorities of the implemented changes included: increasing the military capabilities of NATO (including the command structure reforms), establishing a NATO Response Force, and improvement and development of operational capabilities.

The outcomes of the Prague Summit included changes in the functional command structure, which resulted in establishing the Allied Command Transformation -

6 NATO states were obliged to continue improving their military capability to defend against new warfare, in a high-risk environment. Particular members were also obliged to modernise or purchase new military equipment in areas including: defence against weapons of mass destruction, intelligence, monitoring and surveillance, precision-guided munitions, and tactical transport. 
ACT in Norfolk (the USA), and Allied Command Operation - ACO, based in Mons (Belgium).

The NATO summit in Prague (Górka-Winter 2002) was therefore a significant event regarding the gravity of the decisions concerning the adjustment of the capabilities of the Alliance to known and projected dangers and challenges. NATO states adopted a vast array of measures to defend against threats, regardless of the type of threat (terrorism, proliferation of weapons of mass destruction and their means of delivery), or source (e.g. a terrorist attack carried out from outside the NATO territory). The Prague Summit Declaration states that any potential activities performed by NATO Allies should not be regarded as a threat by any state or organisation. Furthermore, it was assumed that NATO forces should exhibit sufficient mobility to remain in environments under threat of attack for extended periods of time, whether conventional or by means of weapons of mass destruction.

Another crucial outcome of the Prague Summit follows from approving the Prague Capabilities Commitment - PCC. In PCC, the NATO member states committed to continue their efforts towards attaining the military capability to defend against new warfare, in a high-risk environment. Particular members were also obliged to modernise or purchase new military equipment in areas including: defence against weapons of mass destruction, intelligence, monitoring and surveillance, precision-guided munitions, and tactical transport. The commitment document urged particular states to develop specialist capabilities in different fields, which would enable states of lower potential, including certain new members, to contribute their specialist knowledge and assistance to NATO defence capabilities.

Another noteworthy decision of the Prague Summit was the establishment of the NATO Response Force - NRF. These forces give NATO the ability to react immediately should threat emerge. It was resolved that selected units of land, air, maritime and special forces would be allocated and constitute the NRF, according to the objectives of particular operations. The forces operate in 12-month rotational periods, and having been selected by member states to participate in the NRF, they go through a 6-month exercise programme, which aims to integrate particular contingents. The trained forces remain combat ready at immediate notice, at the disposal of NATO Supreme Allied Commander Operations (SACO). 
Considering the wide range of highly dissimilar scenarios that may require NRF activity, the units are allocated by SACO to particular operations, upon close analysis of a given operation's character and demands (Panek 2011, p. 206-211). NATO Response Forces are deployed to fulfil collective defence strategy or for purposes outside Article 5, in crisis response, independently or in support. In particular, NRF operations may involve:

- evacuating non-combatants from the combat zone, particularly UN personnel and other international non-governmental organisation personnel, NATO member state citizens, and other non-combatants designated by NAC. This operation type is typically performed in response to a loss of control over a country under an internal stability control operation, which may involve ethnic armed conflicts;

- preceding the main body to the objective area, i.e. ensuring suitable conditions of occupation and covering the deployment of the main body in the objective area.

- The strategic objectives will be achieved by means of e.g.:

- a show of determination and will to defend the NATO area of responsibility;

- providing immediate NATO support for a state in crisis;

- providing conditions for the projection, occupation and deployment of military power in operational areas;

- supporting antiterrorist operations, the operation in response to, inter alia, terrorist attacks on the area of NATO member states will involve the use of offensive means to reduce the capability of groups and individuals connected with terrorist environments to perform activities against states, organisations and the civilian population. The primary objective of such activities will be to neutralise threat on the part of terrorist organisations through activities aimed at:

- neutralising terrorist groups;

- restricting their chemical and biological attack capabilities by liquidation of production and storage sites;

- performing psychological and information operations;

- protecting forces;

- protecting crucial lines of communication and communication facilities; 
- performing humanitarian operations, with the main objective of providing support to state, international and other organisations helping civil population in crisis;

- demonstration of force, i.e. show of force and show of combat-readiness of NATO forces, manifested by moving forces and publicising their presence, carried out with a view to changing the situation that could be of critical importance to the Alliance or Allied States in the crisis area. Demonstration operations are performed with the aim of:

- demonstrating the bonds between Alliance States;

- deterring potential aggressors;

- exerting or extending the influence on the course of events in the crisis area;

- supporting diplomatic action;

- performing crisis response operations, implementing different measures for maintaining peace, e.g. from supporting civil agencies to initiation of hostilities. The activities are intended to demonstrate the decisiveness of the Alliance to restore peace, security and stability in the state in crisis. The objectives of these operations include:

- providing suitable conditions to resolve crisis peacefully;

- securing conditions for the movement of forces to the operational area;

- performing operations that enforce embargoes, so that the import/export bans on specified goods to/from a given state are observed, and to force the state or a group of states, organisations or individuals to respect international laws or $\mathrm{UN}$ resolutions. NRF is responsible for:

- controlling and enforcing embargoes;

- providing support to other forces and organisations controlling the enforcement of embargoes;

- monitoring and controlling trade and communication routes.

What should be highlighted is the fact that NATO is an organisation which is permanently involved in international expeditionary operations. Therefore, the total transformation of the Alliance into a new organisation with new goals and mandates is not required. What is however needed is to develop the means that will allow these mandates to be carried out. Although the commitments made at the Prague Summit have already produced certain effects, the transformation process is considered not to have been completed as yet. Furthermore, there is 
a shared belief that alongside the changes in the strategic security environment, NATO ought to adjust and develop new capabilities to perform crucial activities in volatile areas, to prevent crises rather than being forced to resolve them.

In recent years, the NATO Network Enabled Capability concept has been vigorously developed to enable operations in the net-centric environment. It is widely regarded as one of the most ambitious NATO initiatives in the fields of command systems, control and communication. The concept merges components of the operational system by means of a developed IT network. The information and data is shared, which significantly improves the understanding of the situation in the theatre of operations, and enhances decision-making in the performance of various operations (Bartoli 2006). In conclusion, regarding the analysis and evaluation of the Alliance capabilities to face the predicted changes in the strategic security environment, it ought to be remarked that should NATO's political influence in volatile areas be insufficient, the role of the Alliance will be marginalised to that of an organisation primarily concerned with responding to crises rather preventing them.

\section{Summary}

The North Atlantic Treaty is a political and military organisation which has always shown high flexibility and adaptability to the changing world. The essence of each transformation has been to respond to threats to international security. Predictions are that the international security environment of the future will be constantly and increasingly changeable, complex, surprising and chaotic. This means that we should expect a constant increase in the level of uncertainty and unpredictability, and, consequently, in the risk indices and the probability calculus of diagnosed threat occurrence, as well as of predicted challenges for the international security.

The future security environment is anticipated to be controlled by three groups of factors: technological, economic and cultural. Technology enhances virtualisation of the contemporary and the future world, while information warfare, crime and conflict in cyberspace are expected to intensify. Economic (financial) factors, predominantly concerning currency value creation, transform microeconomies 
and hamper the effectiveness of fiscal policy and create suitable conditions for criminal and terrorist groups to operate in. Cultural factors, on the other hand, are likely to further the radicalisation and widening of the cultural gaps, polarisation of views on globalisation, such as questioning the advantages of globalisation and emphasising its hazards, e.g. uncontrollable migration.

Major sources of threat and potential future challenges in the constantly evolving international security environment include such factors as: terrorism, proliferation of weapons of mass destruction, climate change, the growing gap between the world of the poor and the rich, demographics, ethnic problems and religious conflicts, fierce competition for the scarce natural resources, international organised crime, economic crises, clashes of political and economic interests between major state actors, revolutionary developments in science and technology and their military implementations.

\section{References}

Admin, 2015. Atomowa przewaga Rosji nad NATO. Przewaga jest ogromna. [online] Available from: <https://www.koniec-swiata.org/atomowa-przewaga-rosji-nad-natoprzewaga-jest-ogromna/> [Accessed 18 Jun 2018].

Balcerowicz, B., Czym jest współcześnie wojna. [online], Available from: files.pwi.edu. pl/files/balcerowicz.doc [Accessed 12 Jul 2018].

Banasik, M., 2015. Zdolności NATO do działań ekspedycyjnych w przyszłym środowisku bezpieczeństwa międzynarodowego. Difin, Warsaw.

Bartoli, M., 2006. Ocena transformacji NATO. Przeglad NATO, 3. [online] Available from: https://www.nato.int/docu/review/2006/issue3/polish/art3.html, [Accessed 24 Jun 2018].

Baylis, J., Wirtz, J., Colin Gray, S. and Cohen, E., 2009. Strategia we wspótczesnym świecie. Wprowadzenie do studiów strategicznych. UJ, Kraków.

Brzeziński, Z., 1990. Plan gry. Nowe Wydawnictwo Polskie, Warsaw.

Dura, M., 2015. Rosja sformowała wojska powietrzno-kosmiczne. Nowy rodzaj sił zbrojnych. [online], Available from: https://www.defence24.pl/rosja-sformowalawojska-powietrzno-kosmiczne-nowy-rodzaj-sil-zbrojnych. [Accessed 11 Jul 2018].

Górka-Winter, B., 2002. Praski szczyt NATO (21-22 listopada 2002 r.) Biuletyn PISM, 102. [online] Available from: https://www.pism.pl/files/?id_plik=350 [Accessed 11 Jul 2018].

Order nr 56 of Minister of National Defence (MON) of 24 December 2013 on the Organisers of Functional Systems (OSF) of Polish Armed Forces. 
Panek, B., 2011. Wielonarodowe operacje reagowania kryzysowego narzędziem realizacji polityki bezpieczeństwa transatlantyckiego. Wydawnictwo AON, Warsaw.

Reiss, B., 2018. Bardzo zimna wojna. [online] Available from: http://www.newsweek.pl/swiat/ polityka/wojna-o-arktyke-i-ropę-naftową-usa-w-tyle-za-rosja,artykuły,408890,1.html [Accesed 10 Jun 2018].

Sloan, E., 2010. DCI: Responding to the US-led Revolution in Military Affairs. The Defence Capabilities Initiative NATO Review No. 2, Summer 2000. In M. Kozub, B. Panek (eds), Sity zbrojne jako narzędzie bezpieczeństwa międzynarodowego, Łódź-Warsaw.

United States Department of Defense, 2011. Joint Operations, Joint Publication 3-0.

Wrzosek, M., 2013. Polska, Unia Europejska, NATO wobec wyzwań i zagrożeń. Wydawnictwo AON, Warsaw. 